\title{
Obituary
}

\section{Rolfe Cartwright Tomlinson (1 September 1925-10 October 2015)}

Journal of the Operational Research Society (2016) 67(3), 377. doi:10.1057/jors.2015.116

Rolfe Cartwright Tomlinson died on 10 October 2015, a few weeks after his ninetieth birthday. He was for many years a leading figure in the Operational Research (OR) world both in the United Kingdom and internationally. He was President of the OR Society in 1974/1975 (at the time of his death he was the oldest surviving Past-President in terms of age and period of office) and President of EURO, the Association of European Operational Research Societies, in 1981/1982. He was honoured by the OR Society being both a Companion and a recipient of the Beale Medal. His influence on OR was both by his direct contribution and by his stimulation and encouragement of others. He projected high aspirations that he sought to attain by persuasion and cooperative working. He had the happy knack of inspiring people, drawing the best out of them and stimulating their development. Many of those who worked with and under him went on to occupy significant positions in the worlds of academe and practice.

Rolfe graduated from Cambridge with a first-class degree in Mathematics before his twentieth birthday just as the Second World War was drawing to its close. He went on to obtain a Diploma of Imperial College in Aeronautics and his first job was as an aeronautical engineer at the National Physical Laboratory. In 1950 he began a long association with the National Coal Board working first as a statistician when he did important work on the control of the underground environment and the sampling methods appropriate to its effective control. In 1960 he moved into the OR Group of the NCB, first as its Deputy Head before becoming, in 1965, its Head. In 1977 he moved to IIASA, the International Institute for Systems Analysis, in Vienna where he was Head of the Management and Technology Area. In 1980 he returned to the United Kingdom as Professor of Operational Research and Systems in the University of Warwick, a post he occupied until his retirement in 1990 .
The NCB OR Group flourished under his leadership. Building on the foundations laid by his predecessors Pat Rivett and Brian Houlden, he led the Group to its being one of the largest in size and, more importantly, in influence in the United Kingdom. There were few spheres of NCB activity, from the operational to the strategic, to which the OR Group did not have an (often substantial) input. This success was in large measure because of Rolfe's grasp of what kinds of contribution OR could make and where, and his facility for persuading the relevant senior management that OR could help them. He took the qualities that ensured the success of the NCB OR Group with him to periods of equal achievement at IIASA and Warwick. At Warwick he was the first professor of Operational Research and Systems and Head of the ORS Group. During his 10 years at Warwick the Group developed strongly under his leadership and by the time of his retirement was recognized as one of the leading OR groups in the United Kingdom and indeed Europe. He also served as Head of the Centre for Research into Business and Administration in the Business School and was instrumental in setting up the Business School's first part-time modular degree, the MSc in Business Management Systems. In the course of his career he published extensively and, in particular, wrote and spoke authoritatively about the process and management of OR. He also edited important texts including an influential series published under the auspices of the OR Society.

Outside his professional life, Rolfe was a baritone of professional standard and engaged in public life in various ways, including as an active member of the Anglican Church and as a member and Deputy Chair of the Coventry Health Authority. He is survived by his third wife Margaret (his two previous wives, Jill and Helen, both died prematurely) and by his large extended family of his own three children and his stepchildren, their spouses, their children and their grandchildren. A happy memory of any Tomlinson family occasion is the high quality of the musical entertainment provided by the family.

Rolfe Tomlinson will be missed by many but his influence and the achievements he leaves make a celebration of his life as appropriate as commiseration at his death.

Robert Dyson George Mitchell

This Obituary was previously published by the same author as: Rolfe Cartwright Tomlinson, Former President of EURO 1 September 1925 - 10 October 2015 , European Journal of Operational Research (2015), http://dx.doi.org/10.1016/j.ejor.2015.12.020. 